\title{
RANCANG BANGUN APLIKASI NEW NORMAL COVID- 19 DETEKSI PENGGUNAAN MASKER MENGGUNAKAN HAAR CASCADE CLASSIFIER
}

\author{
Ahmadi $^{\mathrm{a}, 1, *}$, Ade Chandra Saputra ${ }^{\mathrm{b}, 2}$, Ariesta Lestari ${ }^{\mathrm{c}, 3}$ \\ ${ }^{a}$ Universitas Palangka Raya, T. Tilung XXII, Palangka Raya \\ b Universitas Palangka Raya, Yos Sudarso 3, Palangka Raya \\ ${ }^{1}$ dataahmadi2020@gmail.com *; ${ }^{2}$ adechandra@it.ac.upr.id; ${ }^{3}$ aries22ta@ gmail.com \\ * corresponding author
}

ARTICLE INFO

Keywords

\begin{abstract}
During the COVID-19 pandemic, when in public places, it is required to apply the 4M health protocol, namely wearing masks, washing hands, maintaining distance, and avoiding crowds. In its implementation, there are officers who always maintain and remind people not to violate health protocols. Like remembering to wear a mask.

The mask detection application is made as a computerized surveillance system that can store images of violations of the use of masks and provide warning sounds. Observations, discussions and literature studies are sources of data in this empirical research. Using Python as a programming language assisted with OpenCV for image processing. After passing through the 4 stages of Waterfall, namely Analysis, Design, Manufacturing and Development and Testing, an application is produced where the Raspberry $\mathrm{Pi}$ is a processing tool and images are captured from the camera module with a resolution of $1080 \times 1024$ px. This application can detect the use of masks with an accuracy of $90.5 \%$ using the Machine Learning Haar Cascade Classifier method. Where the condition of the face is a maximum of 30 degrees turned to the side and looked up.
\end{abstract}

\section{PENDAHULUAN}

\subsection{Latar Belakang}

Pada Desember 2019, kasus pneumonia misterius pertama kali dilaporkan di Wuhan, Provinsi Hubei[1]. Selanjutnya virus ini diberi nama Severe Acute Respiratory Syndrome Coronavirus 2 (SARS-COV 2). Transmisi SARS-CoV-2 dari pasien simptomatik terjadi melalui droplet yang keluar saat batuk atau bersin[1]. Cara menghindar dari terpapar Covid-19 adalah dengan menghindari kontak langsung atau menjaga jarak dan menggunakan masker. pada tempat umum biasanya masih terdapat pelanggaran yang terjadi, Sehingga akan ada petugas yang senantiasa menjaga dan mengingatkan agar orang tidak melanggar protokol kesehatan, hal ini mengakibatkan terjadinya kontak langsung antara petugas dan pengunjung. Agar pada proses pengawasan dapat dilakukan menyeluruh dan menghindari kontak langsung. Selain itu ketika menggunakan komputer, hasil pengawasan dapat disimpan berupa gambar pada penyimpanan komputer, atau dikirim melalui sosial media salah satunya adalah Telegram dimana gambar tersebut digunakan sebagai bukti dikemudian hari. Seperti halnya pada penelitian oleh Galang Aprilian Anarki, Karina Auliasari, Mira Orisa, dengan judul "PENERAPAN METODE HAAR CASCADE PADA APLIKASI DETEKSI MASKER" dapat mendeteksi masker dengan total keakuratan tertinggi 88,7\% dan terendah $44,9 \%$. 


\subsection{Tujuan Penelitian}

Tujuan dari penelitian ini yaitu mengimplementasikan Machine Learning dalam pengawasan sebagai pendeteksi penggunaan masker menggunakan Metode Haar Cascade Classifier. Menerapkan Haar Cascade Classifier dalam mendeteksi objek.

\section{TINJAUAN PUSTAKA}

Bagian ini memuat teori-teori pendukung dari metode yang diusulkan untuk pemecahan suatu masalah dan/atau pengembangan dari metode tersebut, yang didasarkan dari referensi yang jelas (buku, jurnal, prosiding dan artikel ilmiah lainnya).

\subsection{Tinjauan Pustaka}

\subsubsection{Penerapan Metode Haar Cascade Pada Aplikasi Deteksi Masker}

Pada penlitian oleh Galang Aprilian Anarki, Karina Auliasari, Mira Orisa, dengan judul "PENERAPAN METODE HAAR CASCADE PADA APLIKASI DETEKSI MASKER" hasil dari penelitian ini adalah aplikasi dapat mendeteksi masker dari citra yang bersumber dari foto atau video dari webcam internal maupun eksternal dengan baik, dengan total keakuratan tertinggi $88,7 \%$ dan terendah $44,9 \%$. Fitur peringatan yang berupa audio dan memotret juga dapat bekerja dengan baik[2].

\subsubsection{Sistem Deteksi Wajah dengan Menggunakan Metode Viola-Jones}

Penelitian ini mendapatkan nilai akurasi sistem deteksi wajah sebesar 90,9\%. Hasil lain yang didapatkan adalah posisi wajah yang tegak/tidak tegak menentukan keberhasilan deteksi wajah tersebut[6].

\subsubsection{Desain sistem deteksi objek real time dengan Metode Haar Cascade Classifi}

Objek yang ingin diamati dapat dideteksi langsung oleh CCTV secara detail. Sistem ini dapat memberikan informasi kepada pengguna secara real-time untuk mengamati langsung keadaan barang barang berharga di dalam suatu ruangan dengan CCTV yang sudah di beri desain algoritma, hal ini dapat meminimalkan aksi kriminal seperti pencurian dan pengrusakan barang barang berharga[3].

\subsection{Teori-Teori Pendukung \\ 2.2.1. COVID-19}

Virus Corona atau severe acute respiratory syndrome coronavirus 2 (SARS-CoV 2) adalah virus yang menyerang sistem pernapasan. Penyakit karena infeksi virus ini disebut COVID-19. Virus Corona bisa menyebabkan gangguan ringan pada sistem pernapasan, infeksi paru-paru yang berat, hingga kematian. COVID-19 pertama dilaporkan di Indonesia pada tanggal 2 Maret 2020 sejumlah dua kasus. Data 31 Maret 2020 menunjukkan kasus yang terkonfirmasi berjumlah 1.528 kasus dan 136 kasus kematian. Saat ini, penyebaran SARS-CoV-2 dari manusia ke manusia menjadi sumber transmisi utama sehingga penyebaran menjadi lebih agresif[1].

\subsubsection{Computer Vision}

Virus Computer Vision merupakan salah satu cabang ilmu pengetahuan yang bertujuan untuk membuat suatu keputusan yang berguna mengenai objek fisik nyata dan keadaan berdasarkan sebuah gambar atau citra.

\subsubsection{Machine Learning}

Machine Learning merupakan cabang ilmu dari Artificial Intelligence yang memungkinkan komputer memiliki kemampuan untuk belajar tanpa perlu di program lagi. Machine learning berhubungan dengan computational statistics yang berfokus pada suatu prediksi atau pembuatan keputusan berdasarkan penggunaan komputer. Beberapa implementasi dari machine learning adalah text analysis, image processing, finance, search and recommendation engine, speech understanding.

\subsubsection{Haar Cascade Classifier}


Haar Cascade classifier merupakan metode yang digunakan dalam pendeteksian obyek. Metode ini juga dikenal dengan metode viola jones. Salah satu metode pendeteksian objek yang cukup populer adalah metode Viola Jones, yang diusulkan oleh Paul Viola dan Michael Jones pada tahun 2001. Terdapat empat kunci utama di dalam metode pendeteksian objek Viola Jones, yaitu: Fitur segi empat sederhana disebut sebagai fitur Haar. Integral image (citra integral) untuk pendeteksian fitur secara cepat. Metoda machine learning AdaBoost (algoritma boosting). Cascade Classifier (Classifier bertingkat) untuk menghubungkan dan mengelompokkan banyak fitur secara efisien.

Secara umum Haar-Like Feature digunakan dalam mendeteksi objek pada image digital. Nama Haar merujuk pada suatu fungsi matematika (Haar Wavelet) yang berbentuk kotak, prinsipnya sama seperti pada fungsi Fourier. Awalnya pengolahan gambar hanya dengan melihat dari nilai RGB tiap pixel, namun metoda ini ternyata tidaklah efektif.

Fitur haar (haar like feature) adalah pengambilan pixel pada citra membentuk segi empat sederhana yang dibagi menjadi dua bagian, satu bagian gelap dan satu bagian terang. Adanya fitur haar ditentukan dengan cara mengurangi rata-rata pixel pada daerah gelap dari rata-rata pixel dari daerah terang. Jika nilai perbedaan itu diatas nilai ambang atau threshold, maka dapat dikatakan bahwa fitur itu ada. Untuk menentukan ada tidaknya dari ratusan fitur haar pada sebuah citra dan pada skala yang berbeda secara efisien, Viola Jones menggunakan teknik yang dinamakan citra integral atau integral image.

Integral Image adalah sebuah citra yang nilai tiap pikselnya merupakan penjumlahan dari nilai piksel kiri atas hingga kanan bawah. Untuk memudahkan proses perhitungan nilai dari setiap fitur Haar pada setiap lokasi gambar digunakan teknik yang disebut citra integral. Secara umum integral mempunyai makna menambahkan bobot, bobot merupakan nilai-nilai piksel yang akan ditambahkan ke dalam gambar asli. Dengan mendapatkan nilai dari citra integral maka jumlah dari seluruh piksel yang ada dalam setiap persegi panjang dapat dihitung dengan empat nilai. Nilai-nilai ini merupakan piksel pada citra integral yang bertepatan dengan sudut-sudut persegi panjang yang ada pada citra masukkan.

Algoritma AdaBoost (Adaptive Boosting) adalah algoritma Machine learning untuk memilih subset fitur terbaik di antara semua fitur yang tersedia. Keluaran dari algoritma ini adalah sebuah pengklasifikasi (Fungsi Prediksi, Fungsi Hipotesis) yang disebut "Strong Classifiers". Strong Classifiers terdiri dari kombinasi linier "Weak Classifiers" (fitur terbaik). Untuk memilih fitur yang spesifik yang akan digunakan dan untuk mengatur nilai ambangnya (threshold), Viola dan Jones menggunakan sebuah metode machine learning yang disebut AdaBoost.

Cascaded classifier merupakan suatu metode pengklasifikasian bertingkat, dimana input dari setiap tingkatan merupakan output dari tingkatan sebelumnya. Cascade classifier dirancang sedemikian rupa untuk meningkatkan tingkat pendeteksian dan mengurangi jumlah positif palsu.

\subsubsection{Raspberry Pi}

Raspberry Pi, sering disingkat dengan nama Raspi, adalah komputer papan tunggal (singleboard circuit; SBC) yang seukuran dengan kartu kredit yang dapat digunakan untuk menjalankan program perkantoran, permainan komputer, dan sebagai pemutar media hingga video beresolusi tinggi.

\section{METODE PENELITIAN}

Jenis penelitian ini adalah penelitian empiris, yaitu penelitian dengan adanya data-data lapangan sebagai sumber data utama, seperti hasil wawancara dan observasi. Metodologi yang diperlukan untuk tugas akhir ini terdiri dari beberapa tahap seperti: tahap pengumpulan data, tahap pengembangan, hingga menghasilkan kesimpulan. 


\subsection{Model Pengembangan Sistem}

Metode yang digunakan pada pengembangan Aplikasi Deteksi Masker menggunakan waterfall. Model ini sering disebut juga dengan classic life cycle atau metode waterfall. Namun pada penelitian kali ini, peneliti mengembangkan Metode Pengembangan Perangkat Lunak menurut Rosa dan Shalahuddin, agar dapat sesuia dengan penelitian yang dilakukan.

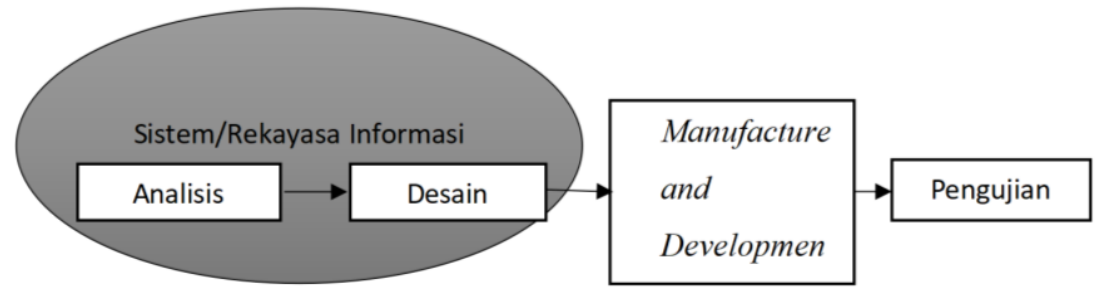

Gambar 1 pengembangan MPPL Rosa dan Salahuddin

\subsection{Analysis}

Tahap pengumpulan kebutuhan dilakukan dengan studi literatur dan studi pustaka. Melalui pengumpulan kebutuhan tersebut, peneliti memperoleh data mengenai keamanan pengawasan pintu masuk dengan diawasi langsung. komponen untuk membangun produk, tools untuk pengembangan sistem, teori yang akan digunakan, serta data untuk desain dan proses pembuatan alat dan sistem. Hal yang dilakukan yaitu Mendefinisikan Ruang Lingkup, Analisis Sistem Berjalan, Analisis Sistem Usulan, Analisis Kebutuhan Fungsional Sistem dan Analisis Kebutuhan Hardware.
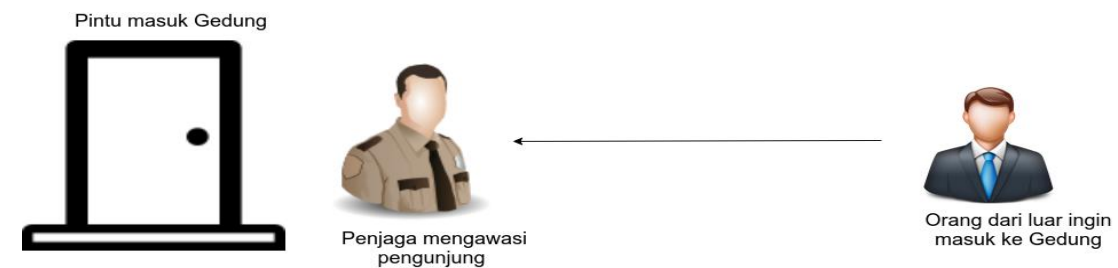

Gambar 2 pengembangan MPPL Rosa dan Salahuddin

Gambar ilustrasi diatas menunjukan bahwa sistem yang berjalan saat ini masih menggunakan data manusia untuk selalu memperhatikan pengunjung yang datang ke Gedung rektorat Universitas Palangka Raya.

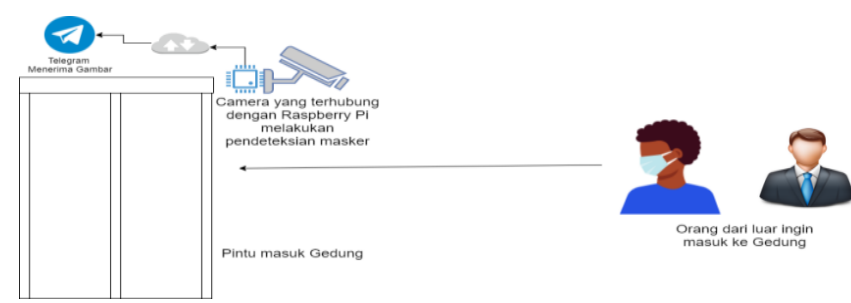

Gambar 3 pengembangan MPPL Rosa dan Salahuddin 


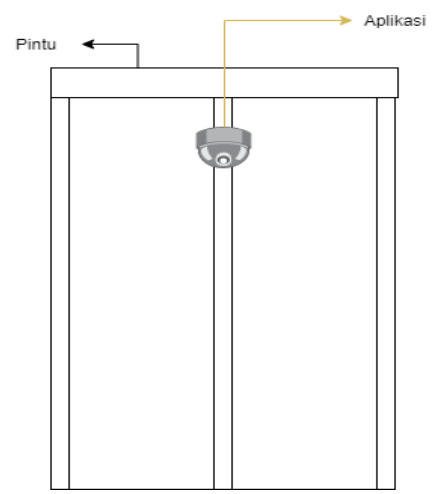

Gambar 4 pengembangan MPPL Rosa dan Salahuddin

Terlihat pada gambar penempatan akan berada tepat di depan pintu, dengan ketinggian dari 1.5 hingga $2 \mathrm{~m}$ disangga oleh tripod. pengunjung dapat masuk dengan melewati kiri dan kanan Aplikasi.

\subsection{Design}

Pada penelitian ini beberapa tahapan yang akan dilakukan adalah pengambilan dataset, proses training, implementasi pada proses Pendeteksi penggunaan masker dan proses pemberian peringatan. Desain sistem real time deteksi objek ini menggunakan beberapa perangkat lunak yang sangat penting untuk proses pembuatan desain algoritmanya. Proses pembuatan perancak lunak dan instalasi perangkat lunak dapat dilihat dari diagram alir dibawah ini.

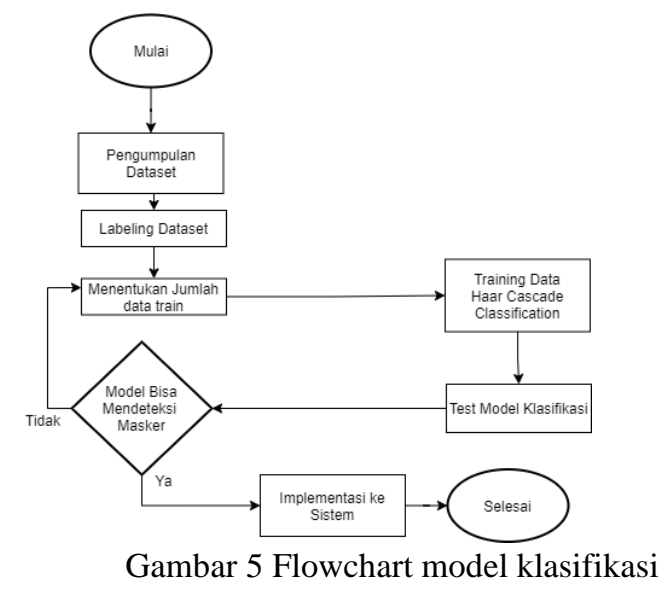

Selanjutnya adalah pengimplemtasian model pada perangkat keras. Berikut desain Perangkat Lunak yang diterapkan pada perangkat keras. 


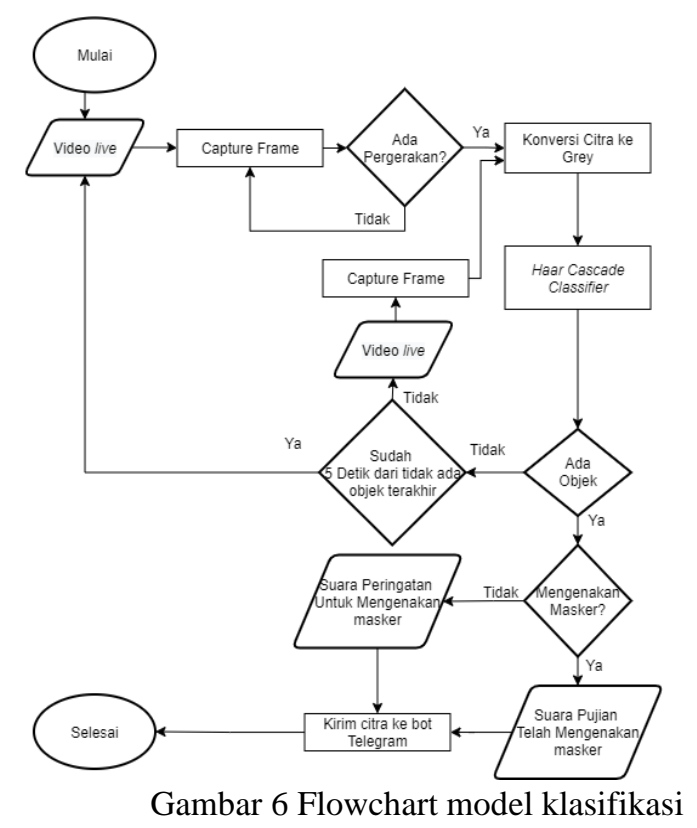

Sistem pada Raspberry Pi dimulai dengan Input Citra melalui Modul Kamera, lalu dari input citra ini akan diambil Capture gambar yang akan dilakukan Konvolusi Citra, apakah orang menggunakan masker atau tidak dimana akan memberikan peringatan melalui Speaker dan mengirim gambar wajah orang tanpa masker ke telegram.

Desain perangkat keras yang akan dirancang berdasarkan gambar 3.2 dimana Modul Kamera, Raspberry Pi dan Speaker terintegrasi dan saling terhubung.

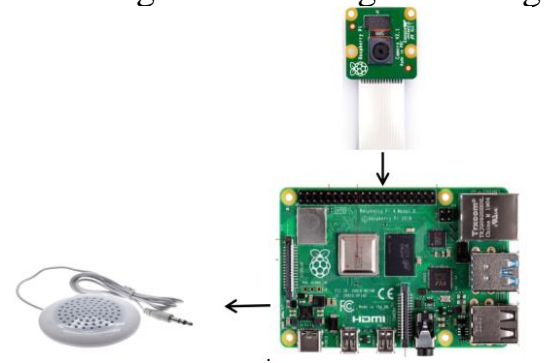

Gambar 7 Flowchart model klasifikasi

\section{PEMBAHASAN}

4.1 Manufackture and Development

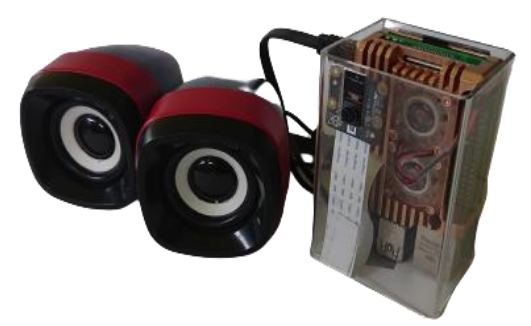

Gambar 8 Rangkaian Aplikasi 
Terlihat pada rancangan, Modul kamera Raspberry Pi dihubungkan pada port kamera. Output suara dikeluarkan oleh Speaker yang dihubungkan menggunakan kabel $3.5 \mathrm{~mm}$ melalui lubang jack audio pada Raspberry Pi. Sedangkan untuk penyimpanan gambar dikirim melalui internet dimana dihubungkan melalui $L A N$ atau WIFI. Untuk menghidupkan sistem ini diperlukan daya listrik yang didapat melalui port USB tipe $C$ pada Raspberry P $i$.

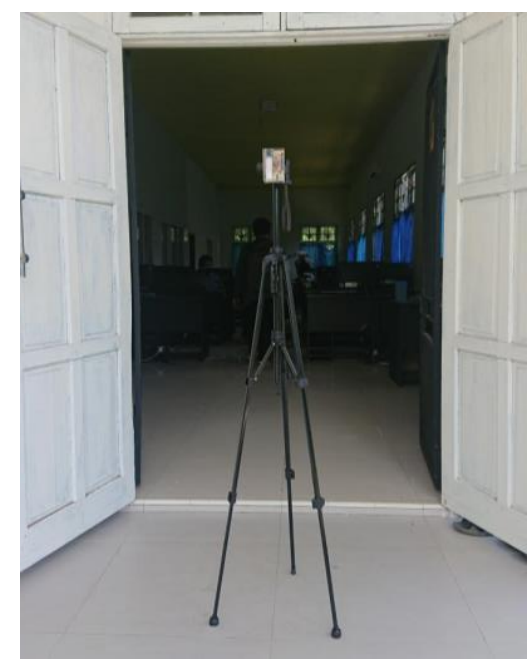

Gambar 9 peletakan alat

Dataset yang digunakan untuk tahapan pelatihan pembuatan model adalah dataset yang didapat website penyedia dataset yaitu web kaggle dengan situs www.kaggle.com berjudul dataset Face Mask $12 \mathrm{~K}$ Images Dataset dengan alamat www.kaggle.com/ashishjangra27/facemask-12k-images-dataset yang diupload oleh pemilik akun kaggle ashish jangra.

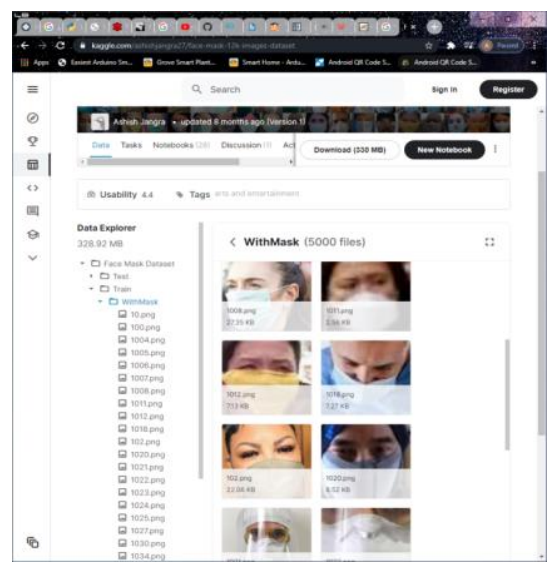

Gambar 10 dataset pada website Kaggle

Dataset yang digunakan sebanyak 3900 untuk label Positive dan 4000 untuk label Ngative, dikarenakan keterbatasan dari device untuk melatih model sehingga memerlukan waktu yang lama dalam melakukan training.Untuk melakukan training sebanyak 3900 dataset dengan label WithMask dan 4000 dataset negative, diperlukan waku 3 hari 19 jam 7 menit training. Berikut tampilan waktu akhir training model. 
Untuk mendapatkan model Machine Learning yang dapat memberikan hasil yang diinginkan, diperlukan tahapan evaluasi model yang telah ditraining. Salah satu cara mengetahui kinerja model adalah dengan mengukur akurasinya. Ada dua konsep pada split validation: training error dan test error. Pada penelitian ini peneliti menggunakan metode Split Validation training error. Dalam mengevaluasi performance algoritma dari Machine Learning (ML) (khususnya supervised learning), digunakan acuan Confusion Matrix. Confusion Matrix merepresentasikan prediksi dan kondisi sebenarnya(aktual) dari data yang dihasilkan oleh algoritma ML.

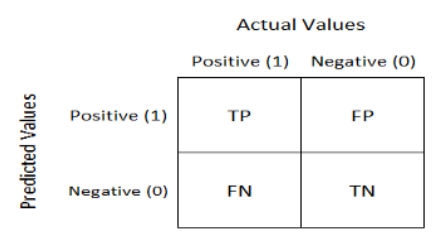

Gambar 11 Matriks Confusion

Data test yang digunakan paling besar yaitu $30 \%$ dari total data antara data training dan data test atau 3.386 data dari 11.286, yang terbagi lagi menjadi dua label. Jadi $30 \%$ data test merupakan $30 \%$ dari data total.

Tabel 1 hasil uji model

\begin{tabular}{ccc}
\hline \multirow{2}{*}{ Banyak Citra } & \multicolumn{2}{c}{ Akurasi } \\
\cline { 2 - 3 } & Positif (\%) & Negatif (\%) \\
\hline $10 \%$ & 92,56 & 89,0 \\
\hline $15 \%$ & 92,99 & 89,34 \\
\hline $20 \%$ & 92,05 & 89,5 \\
\hline $25 \%$ & 91,79 & 89,9 \\
\hline $30 \%$ & 88,28 & 89,75 \\
\hline
\end{tabular}

Terlihat pada tabel diatas, model dapat mendeteksi objek sebesar $88,28 \%$ untuk persentasi terendah mendeteksi objek berlabel positif. sedangkan untuk rata-rata persentasi terdeteksinya objek dengan berbagai macam jumlah data uji dari dua label, model memiliki persentasi akurasi sebesar 90,5\% . pada data diatas terlihat juga bahwa perbedaan jumlah data uji tidak banyak berpengaruh terhadap nilai akurasi dari model.

Tabel 2 Data Uji dengan data kerumunan

\begin{tabular}{|c|l|}
\hline Citra & Keterangan \\
\hline & \\
\hline
\end{tabular}


JURNAL TEKNOLOGI INFORMASI

Jurnal Keilmutan din Apilkasi Bidtang Teknik Informatilka
[E-ISSN 2656-0321]

[Vol 15 No 2]

[ Agustus 2021]

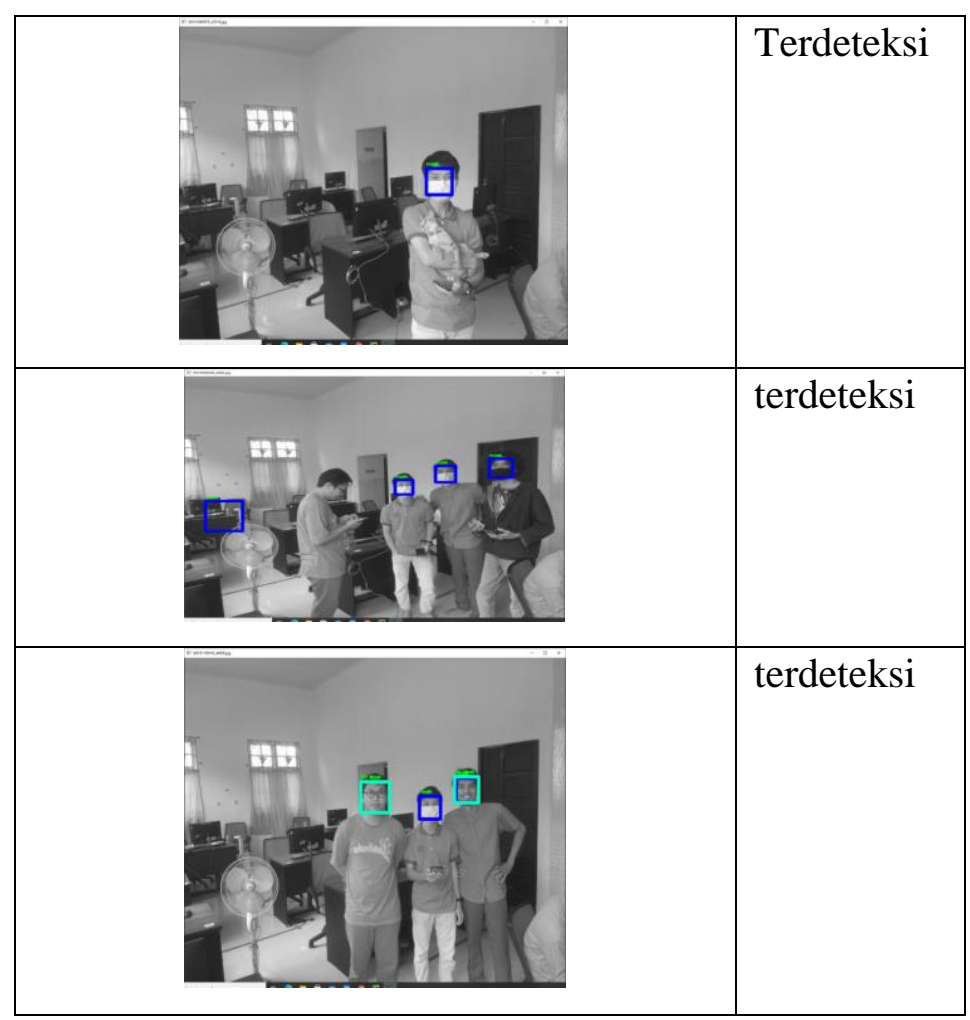

Tabel 3 hasil uji kemiringan 


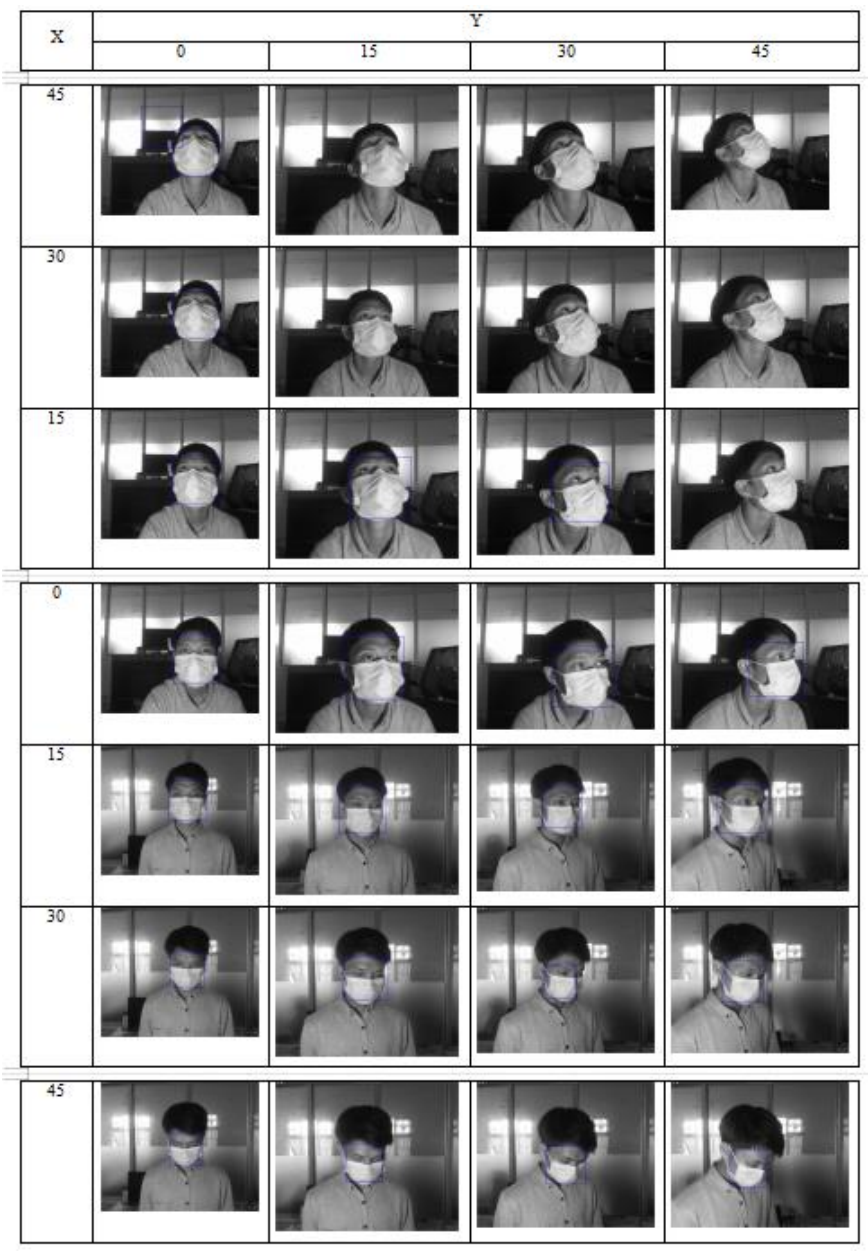

Setelah melakukan pengujian menggunakan Blackbox terhadap fungsi-fungsi yang terdapat pada Aplikasi baik yang dapat dikontol atau diberi perintah melalui Telegram petugas maupun fungsi otomatis dari Aplikasi, dihasilkan keluaran atau hasil yang diharapkan sesuai dimana pengguna dapat menggunakan fungsi dari sistem sebagai mana mestinya.

\section{KESIMPULAN}

Terdapat permasalahan dalam pengawasan dan penjagaan pintu pada saat New Normal, dimana pengawas diharuskan memberi peringatan dengan mendekat serta pengawas tidak mampu memberikan bukti bahwa seorang pengunjung pernah berada disana tidak menggunakan masker. Hingga dilakukanlah penelitian dengan judul "Rancang Bangun Aplikasi New Normal COVID19 Deteksi Penggunaan Masker Menggunakan Haar Cascade Classifier". Dimana telah dibahas pada bab sebelumnya penelitian ini menggunakan Waterfall sebagai Metode Pengembangan Perangkat Lunak. Empat tahapan yang dilalui yaitu Analisis, Desain, Manfacture dan Development serta pengujian. Sistem ini dibangun dengan bahasa pemrograman Python dan OpenCV sebagai Library pemeroses citra, yang diimplementasikan pada rangkaian Raspberry Pi dan modul kamera sebagai alat komputasi dan input citra. Kamera yang digunakan beresolusi 8 mp. Digunakan pula Speaker dan Telegram sebagai Output yang dapat dikelola oleh Petugas. 
Karena OS yang digunakan pada Raspberry adalah Raspbian maka IDE yang digunakan adalah Thonny IDE. Kemudian system diuji menggunakan pengujian Black Box.

Pada saat Development, model hasil training demgan rasio data uji dan data test $70: 30$ diuji menggunakan metode Split validation. Didapat hasil uji model dengan akurasi dapat mendeteksi objek sebesar 90,5\%. Model tersebut memiliki dataset 3900 untuk label positive dan 4000 untuk dataset label negative. Dan pada implementasi pada perangkat keras, didapatkan hasil bahwa Aplikasi dapat mendeteksi objek dengan metode Haar Cascade Classifier, dimana pada penelitian ini adalah Wajah dengan masker dan Wajah Tanpa Masker dengan jarak 3 Meter jika menggunakan resolusi 640 x 480 dimana persentasinya adalah 100\% namun pada jarak lebih dari 3 meter aplikasi tidak mampu mendeteksi objek dengan benar. Sedangkan untuk resolusi $1240 \mathrm{x}$ 1024 dapat mendeteksi objek dalam jarak 5 meter sebesar 90\%. Besar sudut kemiringan wajah yang dapat dideteksi oleh aplikasi sebesar 30 derajat untuk menoleh keatas dan kesamping dan 45 derajat untuk menoleh kebawah. Aplikasi juga dapat mendeteksi beberapa objek wajah dalam satu citra ketika didalam satu citra tersebut terdapat beberapa orang. Setelah mendeteksi objek, Aplikasi berhasil memberi Output berupa suara melalui speaker dan gambar wajah orang tanpa masker ketelegram.

\section{Daftar Pustaka}

[1] A. Susilo et al., "Coronavirus Disease 2019: Tinjauan Literatur Terkini," J. Penyakit Dalam Indones., vol. 7, no. 1, p. 45, 2020, doi: 10.7454/jpdi.v7i1.415.

[2] G. Aprilian Anarki, K. Auliasari, and M. Orisa, "Penerapan Metode Haar Cascade Pada Aplikasi Deteksi Masker," JATI (Jurnal Mhs. Tek. Inform., vol. 5, no. 1, pp. 179-186, 2021, doi: 10.36040/jati.v5i1.3214.

[3] I. S. Pratama, Muhammad Rizky; Rizal, Achmad; Sumaryo, "Desain Sistem Deteksi Objek Real Time Dengan Metode Haar Cascade Classifier Real Time Object Detection System Design Using Haar Cascade Classifier Method," vol. 7, no. 1, pp. 26-34, 2020.

[4] P. Viola and M. Jones, "Rapid object detection using a boosted cascade of simple features," Proc. IEEE Comput. Soc. Conf. Comput. Vis. Pattern Recognit., vol. 1, no. February, pp. 1-8, 2001, doi: 10.1109/cvpr.2001.990517.

[5] K. Pemprov et al., "SK Gubernur kalimantan tengah," vol. NOMOR 43 T, no. PERATURAN GUBERNUR KALIMANTAN TENGAH, pp. 1-6, 2020.

[6] A. R. Syafira, "Sistem Deteksi Wajah Dengan Modifikasi Metode Viola Jones," Emit. J. Tek. Elektro, vol. 17, no. 1, pp. 26-33, 2017, doi: 10.23917/emitor.v17i1.5964. 